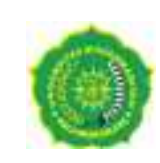

UMP
TUNAS

JURNAL PENDIDIKAN EKONOMI

http://journal.umpalangkaraya.ac.id/index.php/neraca Volume 5 Nomor 2, Juni 2020 (17-23)

\title{
IMPLEMENTASI MODEL PEIMBELAJARAN KOOPERATIF TIPE GROUP INVESTIGATION (GI) BERBANTUAN MEDIA GRAFIS UNTUK MENINGKATKAN HASIL BELAJAR MATEIMATIKA PESERTA DIDIK PADA KELAS IV-D IMIN 2 KOTA PALANGKA RAYA \\ Implementation Of Type Group Investigation (GI) Cooperative Learning Models Assisted Graphic Media To Improve Mathematical Learning Results Students In Kelas IV-D MIN 2 Palangka Raya City \\ 'Rita Rahmaniati dan ${ }^{2}$ Mitranita \\ Universitas Muhammadiyah Palangkaraya, Palangka Raya, Kalimantan Tengah, Indonesia \\ 2Universitas Muhammadiyah Palangkaraya, Palangka Raya, Kalimantan Tengah, Indonesia
}

\section{ARTIKEL INFO}

Diterima

Mei 2020

Dipublikasi

Juni 2020

*e-mail :

rahmaniatirita@gmail.c om

\section{ABSTRAK}

Penelitian ini bertujuan untuk : (I) Untuk mengetahui peningkatan aktivitas belajar peserta didik kelas IV-D MIN 2 Kota Palangka Raya pada saat pembelajaran matematika menggunakan Model pembelajaran kooperatif tipe group investigation berbantuan media grafis. (2) Untuk mengetahui peningkatan hasil belajar peserta didik kelas IV-D MIN 2 Kota Palangka Raya pada saat pembelajaran matematika dengan menggunakan model pembelajaran kooperatif tipe group investigation dan media grafis. Subjek dalam penelitian ini adalah peserta didik kelas IV-D MIN 2 Kota Palangka Raya yang berjumlah sebanyak 34 orang peserta didik. Metode dalam penelitian ini menggunakan metode Penelitian Tindakan Kelas (PTK), menggunakan model pembelajaran kooperatif tipe group investigation berbantuan media grafis. Hasil penelitian menunjukan bahwa: (I) Meningkatnya aktivitas belajar peserta didik dengan menggunakan model pembelajaran kooperatif tipe group investigation berbantuan media grafis, (2) Meningkatnya hasil belajar matematika peserta didik sehingga memperoleh nilai rata-rata $8 \mathrm{I}, 17$ dengan ketuntasan klasikal 97,05\%.

Kata kunci: Hasil belajar matematika, Model Kooperatif Tipe Group Investigation, Media Grafis.

\section{ABSTRACT}

The research aim to: (I) To determine the increase in learning activities of students of class IV-D MIN 2 in Palangka Raya City at the time of mathematics learning using cooperative learning model type group investigation assisted by graphic media. (2) To find out the improvement in learning outcomes of students of class IV-D MIN 2 in Palangka Raya City at the time of mathematics learning using cooperative learning model type group investigation and graphic media. The subject of this research is students in class IV-D MIN 2, Palangka Raya City, amounting to 34 students. The method in this study uses the Classroom Action Research (CAR) or (PTK), using cooperative learning model type group investigation assisted by graphic media. The results of this study indicate that : (I) the Increased learning activities of students using cooperative learning model type group investigation assisted by graphic media, (2) the Increased learning outcomes of mathematics students so that they obtain an average score of 81.17 with classical completeness of $97.05 \%$.

Keywords: Mathematics learning outcomes, cooperative type group investigation, graphics. 
Jurnal Pendidikan Guru Sekolah Dasar PENDAHULUAN

Dari hasil observasi yang dilakukan peneliti di kelas IV-D di MIN 2 Kota Palangka Raya, peneliti menemukan beberapa permasalahan terhadap proses pembelajaran: Pertama, beberapa peserta didik tampak bosan dalam mengikuti proses pembelajaran ini terlihat jelas pada saat pendidik menjelaskan peserta didik lebih asyik berbicara dengan teman sebangkunya daripada mendengar penjelasan pendidik. Kedua,kurangnya minat dan motivasi dalam pembelajaran matematika, diduga pendidik dalam menyampaikan materi pembelajaran cenderung bersifat monoton dan kurangnya variasi terhadap model pembelajaran. Ketiga, kurangnya variasi penggunaan media pembelajaran oleh guru sehingga peserta didik kesulitan menterjemahkan materi yang masih abstrak. Permasalahn ini jika dibiarkan berlarut-larut akan berdampak pada hasil belajar peserta didik.

Permasalahan lainnya yang ditemukan dari hasil wawancara awal dengan wali kelas IV-D MIN 2 Kota Palangka Raya, Guru mengatakan bahwa sebagian besar peserta didik kurang memahami pembelajaran matematika, karena pembelajaran matematika di kelas IV-D MIN 2 Kota Palangka Raya itu hanya satu kali pertemuan dalam satu minggu, dan waktu pembelajarannya matematika tersebut yaitu, $6 \times 35$ menit atau sama dengan 6 jam, sehingga sebagian peserta didik berada dalam titik jenuh pada saat pembelajaran matematika berlangsung. Kejenuhan siswa belajar dengan waktu yang panjang juga dapat berdampak pada hasil belajar peserta didik. Hasil belajar peserta didikkelas IV-D MIN 2 Kota Palangka Raya yang diperoleh dari wali kelas IV-D dari 34 peserta didik terdapat I4 orang peserta didik yang mampu mencapai Kriteria Ketuntasan Minimal (KKM). Sementara 20 orang peserta didik masih belum mencapai KKM yang ditentukan sekolah yaitu dengan nilai 65 pada mata pelajaran matematika. Apabila hal ini tidak segera diatasi, maka peserta didik kurang mencapai kemampuan yang diharapkan dalam tujuan pembelajaran dan kurang memiliki bekal untuk melanjutkan materi yang lebih tinggi.

Beberapa alternative dapat dilakukan pendidik agar proses pembelajaran menjadi lebih aktif. Salah satunya dengan menerapkan suatu model pembelajaran yang dapat meningkatkan hasil belajardan aktivitas belajar peserta didik. Salah satu yang dapat digunakan adalah dengandengan mengimplementasikan Modelkooperatif tipe group investigation ( $\mathrm{Gl}$ ) berbantuan media grafis. Group Investigation (GI) merupakan salah satu bentuk pembelajaran kooperatif yang menekankan pada partisipasi dan aktivitas siswa untuk mencari sendiri materi (informasi) pelajaran yang akan dipelajari melalui bahan-bahan yang tersedia, misalnya dari buku pelajaran atau siswa dapat mencari melalui internet. Siswa dilibatkan sejak perencanaan, baik dalam menentukan topik maupun cara untuk mempelajarinya melalui investigasi. Tipe ini menuntut para siswa untuk memiliki kemampuan yang baik dalam berkomunikasi maupun dalam keterampilan proses kelompok. Pembelajaran kooperatif tipe Tipe GI dapat melatih siswa untuk menumbuhkan kemampuan berfikir mandiri. Keterlibatan siswa secara aktif dapat terlihat mulai dari tahap pertama sampai tahap akhir pembelajaran (Kiranawati, 2007). Pembelajaran kooperatif tipe Tipe Glmenuntut para siswa memiliki kemampuan yang baik dalam berkomunikasi maupun dalam keterampilan proses kelompok.

$$
\text { Menurut Setiawan }
$$

mendiskripsikan beberapa kelebihan dari pembelajaran Group Investigation adalah I) dalam proses belajarnya dapat bekerja secara bebas2) memberi semangat untuk berinisiatif, kreatif, dan aktif3) meningkatkan belajar bekerja sama4) Belajar berkomunikasi baik dengan teman sendirimaupun pendidik 5) Peserta didik terlatih 
Jurnal Pendidikan Guru Sekolah Dasar untukmempertanggungjawabkan jawaban

yang diberikan (6) Bekerja secara sistematis. Selin itu, Model pembelajaran Gl juga memiliki kelemahan, yaitu I) sedikitnya materi yang tersampaikan pada satu kali pertemuan 2) sulitnya memberikan penilaian secara personal 3)Diskusi kelompok boasanya berjalan kurang efektif.

Media mempunyai peranan yang sangat penting sekali dalam kegiatan belajar. Media merupakan wahana penyalur informasi belajar atau penyalur pesan. Menurut Gagne (ramayulis, 2002) menyatakan bahwa "media adalah berbagai jenis komponen dalam lingkungan peserta didik yang dapat merangsangnya untuk belajar. Salah satunya adalah media grafis. Menurut Sanjaya (20l5) media grafis adalah media yang mengandung pesan yang dituangkan dalam tulisan, huruf, gambar dan simbol yang mengandung arti. Media grafis juga dapat mengkombinasikan fakta dan gagasan secara jelas dan kuat melalui perpaduan antara pengungkap kata-kata dan gambar. Fungsi Media grafis adalalah untuk menarik perhatian, memperjelas sajian ide, mengilustrasikan atau menghiasi fakta yang mungkin akan cepat dilupakan apabila tidak digrafiskan. Dengan kata lain, media grafis dapat digunakan untuk membantu anak memahami algoritma penjumlahan dan pengurangan dua bilangan bulat. media grafis ini merupakan kombinasi dari perpaduan antara pengungkapan kata-kata dan gambar. Salah satu kelebihan media grafis mudah membuatnya, murah harganya dan mudah di gunakan, bahan-bahan untuk membuatnya mudah dicarinya dan dapat menarik siswa.

\section{METODE PENELITIAN}

Penelitian ini menggunakan rancangan Penelitian Tindakan Kelas (PTK)yaitu suatu studi sistematis terhadap praktik pembelajaran di kelas dengan pembelajaran yang memiliki tujuan untuk memperbaiki dan meningkatkan kualitas proses pembelajaran dan hasil belajar dengan melakukan tindakan tertentu.

Menurut Kemmis dan Mc. Taggart (Sanjaya,W: 20II) Penelitian tindakan adalah suatu bentuk self-inkuiry kolektif yang dilakukan oleh para partisipan di dalam situasi sosial untuk meningkatkan rasonalitas dan keadilan dari praktik sosial atau pendidikan yang mereka lakukan, serta mempertinggi pemahaman mereka terhadap praktik dan situasi di mana praktik itu di laksanakan. Penelitian Tindakan Kelas sebagai salah satu upaya yang dapat dilakukan pendidik untuk meningkatkan kualiatas peran dan tanggung jawab pendidik khususnya dalam pengelolaan pembelajaran.Dari beberapa definisi para ahli tersebut, maka ciri utama dari penelitian tindakan kelas adalah adanya intervensi atau perlakuan tertentu untuk perbaikan kinerja dalam dunia nyata.

Menurut Sangadji dan Sopiah (2010: III-II2) Penelitian Tindakan Kelas terbagi menjadi tiga bagian :

I. Penelitian; kegiatan mencermati suatu obyek serta menggunakan aturan metodologi tertentu untuk memperoleh data atau informasi yang bermanfaat meningkatkan mutu suatu hal yang menarik minat dan penting bagi peneliti.

2. Tindakan; suatu gerak kegiatan yang sengaja dilakukan dengan tujuan tertentu, dalam penelitian ini berbentuk rangkaian siklus kegiatan.

3. Kelas; adalah sekelompok peserta didik yang dalam waktu sama menerima pelajaran sama dari seorang guru.

Berdasarkan penjelasan diatas, maka PTK dapat diartikan sebagai proses pengkajian masalah pembelajaran di dalam kelas melalui refleksi diri dalam upaya untuk memecahkan masalah tersebut dengan cara melakukan berbagai tindakan yang terencana dalam situasi nyata serta menganalisis setiap pengaruh dari perlakuan tersebut.

Kehadiran dan peran peneliti dalam penelitian ini adalah melakukan penelitian 
Jurnal Pendidikan Guru Sekolah Dasar dengan berkolaborasi bersama dengan seorang pendidik kelas guna memperbaiki proses pembelajaran agar sesuai dengan tujuan yang ingin dicapai. Peneliti merupakan perencana, pengajar, pengamat, pelaksana, pengumpul data, penganalisis data dan pelapor hasil penelitian. Kehadiran peneliti di dalam penelitian secara terus menerus dalam waktu yang cukup panjang dan sangat penting artinya agar dapat menghayati apa yang sebenarnya terjadi di tempat penelitian.

Subjek dalam penelitian ini adalah peserta didik kelas IV-D MIN 2 Kota Palangkaraya Tahun pelajaran 2018/ 2019 yang berjumlah 34 orang yang terdiri dari 16 perempuan dan 18 orang laki-laki. Teknik penelitian dalam penelitian ini melalui tes dan observasi. Observasi dalam penelitian ini adalah observasi langsung yaitu observasi dilakukan dengan cara pengamatan secara langsung untuk mengetahui hasil, tingkah laku, aktivitas peserta didik dan pendidik di dalam kelas, dan objek yang diteliti secara langsung saat pembelajaran di kelas.

Data dalam penelitian ini dianalisis secara kualitatif dan kuantitatif. Data kualitatif diperoleh dari aktivitas pendidik dan peserta didik dalam pembelajaran yang dikelola pendidik dengan penerapan model TAl. Sedangkan data kuantitatif berasal dari pretest yang dilakukan diawal pertemuan dan posttest yang dilakukan diakhir pembelajaran dengan rumus:

$$
\overline{\mathrm{X}}=\frac{\sum X}{N}
$$

Keterangan:

$\overline{\mathrm{X}}=$ Nilai rata-rata kelas

$\Sigma X=$ Total nilai yang diperoleh peserta didik

$\mathrm{N}=$ Jumlah peserta didik

$$
T=\frac{\sum s \geq 65}{N} \times 100 \%
$$

Keterangan:

$\sum s=$ Jumlah peserta didik yang mendapatkan nilai sama 65

$\mathrm{N} \quad=$ Banyak peserta didik

$100 \%=$ Bilangan tetap presentase

$\mathrm{TB}=$ Ketuntasan belajar klasikal minimal

$85 \%$

$100 \%=$ Bilangan tetap (presentasi)

\section{HASIL PENELITIAN DAN PEMBAHASAN}

I. Aktivitas Pendidik dan Peserta Didik

Hasil pengamatan terhadap aktivitas pendidik dan peserta didik dalam pembelajaran Matematika pada materi pembulatan dengan yang menggunakan model pembelajaran $G$ berbantuan media grafis, pada saat pembelajaran berlangsung di amati oleh dua orang pengamat yaitu pendidik dan teman sejawat.

Pembelajaran menggunakan model Gl di kelas IV-D MIN 2 Kota Palangka Raya aktivitas pendidik dan peserta didik menunjukkan perkembangan yang baik. Aktivitas pendidik pada siklus I memperoleh nilai rata-rata 2,52 mengalami peningkatan rata-rata 3,70 pada siklus II. Aktivitas peserta didik pada siklus I memperoleh nilai rata-rata 2,54 mengalami peningkatan rata-rata 3,74 pada siklus II.

Aktivitas Pendidik dalam pembelajaran mengalami peningkatan, hal ini dimaksudkan aktivitas pendidik dalam hal membimbing siswa, aktivitas memberikan kesempatan bertanya dan memberi peluang peserta didik untuk lebih aktif dan reaktif terhadap pertanyaan yang diberikan. Aktivitas peserta didik juga mengalami peningkatan, yang awalnya kurang aktif, kurang bersemangat dan kurang kompak dalam kelompok menjadi lebih aktif dengan model pembelajaran $\mathrm{Gl}$. Peserta didik juga lebih kompak bekerjasama dan mampu meningkatkan kemampuan berkomunikasi, mengemukakan pendapat dan mampu bertanya dengan teman sejawat maupun dengan guru. 
Jurnal Pendidikan Guru Sekolah Dasar

Perubahan aktivitas peserta didik pada siklus I dan siklus II menjadi lebih baik dalam pelajaran matematika dengan menerapkan model pembelajarajan kooperatif tipe group investigation berbantuan media grafis. Agar lebih jelas dapat dilihat pada gambar grafik berikut ini:

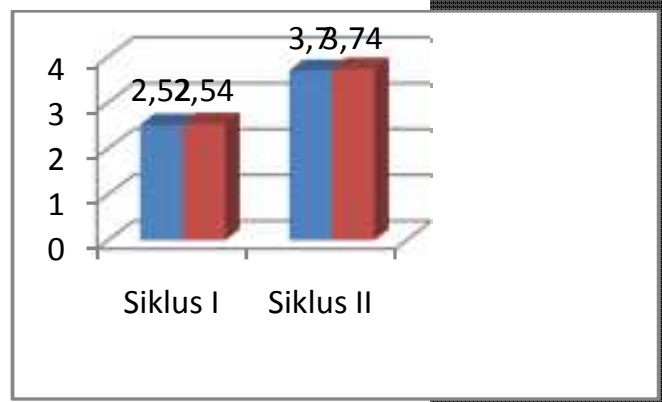

\section{Gambar 2 \\ Grafik Peningkatan Aktivitas Pendidik dan Peserta Didik}

\section{Hasil Belajar Peserta didik}

Pembelajaran dengan model $G I$ ratarata hasil belajar peserta didik 65,69 pada siklus I. Meskipun sdh mencapai KKM tetap secara klasikal belum memenuhi karena ketuntasan secara klasikal 52,94\%. Pada siklus II rata- rata hasil belajar peserta didik mengalami peningkatan dengan rata- rata 81,32 dengan kriteria ketuntasan secara klasikal mencapai $97,1 \%$. Peningkatan aktivitas belajar peserta didik dan hasil belajar diduga karena melalui penerapan.

Hasil belajar matematika pada peserta didik kelas IV-D MIN 2 Kota Palangka Raya dengan menerapkan model pembelajaran kooperatif tipe group investigation berbantuan media grafis, berdasarkan penelitian tindakan kelas (PTK) pada siklus I dan II.

Berdasarkan dari rumusan masalah dan indikator keberhasilan yang ditentukan dalam penelitian ini, dan sesuai dengan data hasil pengamatan (observasi) keaktifan aktivitas peserta didik secara temuan peningkatan hasil belajar peserta didik setelah dilakukan pembelajaran dengan menerapkan model pembelajaran kooperatif tipe group investigation berbantuan media grafis, terbukti bahwa mencapai hasil yang lebih baik dari sebelumnya. Setelah menerapkan menerapkan model pembelajaran kooperatif tipe group investigation berbantuan media grafis terdapat peningkatan hasil belajar peserta didik pada mata pelajaran matematika ini kondisi awal (pre-test) dengan ketuntasan klasikal 4I,I8\%(I4 Peserta didik) yang mendapatkan nilai $\geq 65$ (tuntas) sehingga meningkat pada tes akhir (post-test) siklus II dengan ketuntasan klasikal 97,05\% (33 peserta didik) yang mendapat nilai $\geq 65$ (tuntas) dan hanya ada I peserta didik yang mendapatkan nilai di bawah KKM.

Berdasarkan hasil observasi dan refleksi selama proses pembelajaran dengan materi pembulatan bilangan dapat meningkatkan aktivitas belajar peserta didik dan hasil belajar pada pelajaran matematika dengan menggunakan model pembelajaran kooperatif tipe group investigation berbantuan media grafis dan peserta didik lebih antusias dengan kategori sangat baik dalam mengikuti proses pembelajaran serta dapat mengikuti proses pembelajaran dengan hasil yang lebih baik dari sebelumnya. Perkembangan hasil yang diperoleh dari setiap siklus:

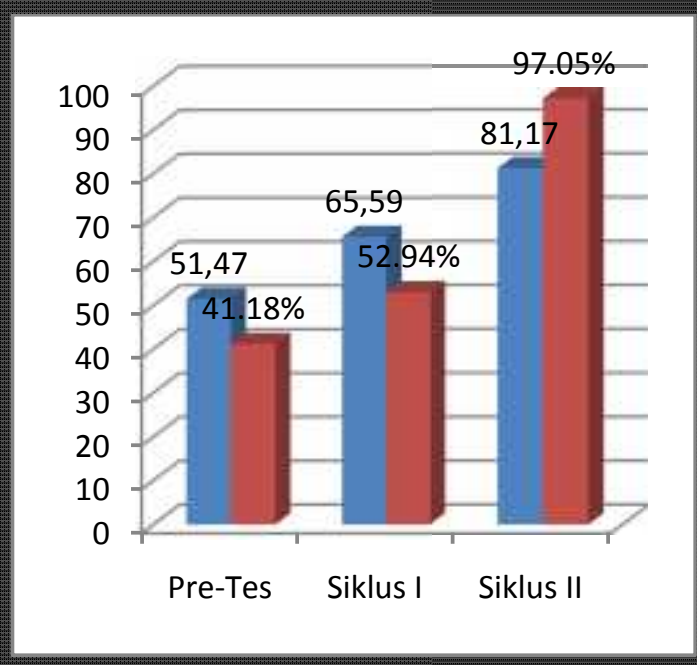

Gambar 3

Grafik Peningkatan Hasil Belajar Peserta Didik Kelas IV-D MIN 2 Kota 
Jurnal Pendidikan Guru Sekolah Dasar

Palangka Raya

Berdasarkan analisis data yang dilakukan terhadap aktivitas peserta didik maka dapatdiperoleh hasil aktivitas peserta didik pada setiap siklusnya. Pada siklus I, aktivitas peserta didik memperoleh skor ratarata 2,54danPada siklus II aktivitas peserta didik memperoleh skor rata-rata 3,74. Hal ini menunjukan bahwa aktivitas peserta didik pada saat peneliti menggunakan model pembelajaran kooperatif tipe group investigation peserta didik aktif, cepat memahami materi yang diajarkan serta tercipta kerja sama yang baik dalam kelompok saat pembelajaran berlangsung dan berani mengemukakan pendapatnya.

\section{KESIMPULAN}

Aktivitas belajar peserta didik kelas IVD MIN 2 Kota Palangka Raya tahun pelajaran 2018/2019 pada kategori sangat baik pada saat proses pembelajaran matematika dengan menerapkan model pembelajaran kooperatif tipe group Investigation berbantuan media grafis dikatakan sangat baik. Ada peningkatan hasil belajar peserta didik kelas IV-D MIN2 Kota Palangka Raya tahun pelajaran 2018/2019 pada kategori sangat baik pada saat proses pembelajaran matematika dengan menerapkan model pembelajaran kooperatif tipe group Investigation berbantuan media grafis dapat dikatakan meningkat atau mengalami peningkatan.

Hasil penelitian tindakan kelas (PTK) ini dapat di rekomendasikan untuk beberapa pihak, yaitu:

\section{Bagi Kepala Sekolah}

Penelitian ini dapat dijadikan sebagai acuan untuk memberikan informasi tentang pentingnya menggunakan model pembelajaran untuk meningkatkan hasil belajar peserta didik, pada mata pelajaran matematika dengan menggunakan model pembelajaran group investigation serta dengan menggunakan media pembelajaran grafis agar peserta didik terlibat aktif dan termotivasi dalam pembelajaran.

\section{Bagi Guru}

Agar dapat memaksimalkan dan mengupayakan penggunaan model serta media pembelajaran untupk meningkatkan aktivitas dan hasil belajar matematika atau pun pembelajaran lain, salah satunya yaitu dengan menggunakan model pembelajaran group investigation berbantuan dengan media grafis.

3. Bagi Peserta Didik

Agar lebih aktif dalam proses pembelajaran sehingga hasil belajar dapat meningkat dan selalu berusaha untuk terus berkembang dalam menerima ilmu yang diberikan oleh guru.

\section{DAFTAR PUSTAKA}

Fathurrohman Pupuh, M. Sobry Sutikno. 2014. Strategi Belajar Mengajar Melalui Penanaman Konsep Umum \& Konsep Islam, Bandung: PT Refika Aditama.

Hendri. 2016. Students' Ability To Use Descriptive Adjective In Sentence. Pedagogik: Jurnal Pendidikan, I I(I): I423.

Kunandar. 2013. Langkah Mudah Penelitian Tindakan Kelas Sebagai Pengembangan Profesi Guru, Jakarta: PT Raja Grafindo Persada.

Putra, Chandra Anugrah. 2017. Pemanfaatan Teknologi Gadget Sebagai Media Pembelajaran. Bitnet : Jurnal Pendidikan Teknologi Informasi, 2(2): I- I0.

Riadin, Agung \& Cici Liani Fitriani. 2018. Upaya Meningkatkan Hasil Belajar Ipa Menggunakan Model Pembelajaran Kooperatif Tipe Jigsaw Dengan Berbantuan Media Alat Peraga Konkret Pada Peserta Didik Kelas V SDN-4 Kasongan Baru Tahun Pelajaran 2016/2017. Pedagogik: Jurnal Pendidikan I3(2): |-5

Rusman. 2014. Model-Model

PembelajaranMengembangkan

Profesionalisme Guru, Jakarta:Rajawali Pers. 


\section{TUNAS}

Jurnal Pendidikan Guru Sekolah Dasar

Sanjaya Wina. 2015. Perencanaan dan Desain

Sistem Pembelajaran, Jakarta: Prenada Media Group.

Santya. 2007. Metodologi Penelitian Tindakan Kelas, Singaraja:Universitas Pendidikan Ganesa.

Setiawan, M Andi. 20I5. Model konseling kelompok dengan teknik problem solving untuk meningkatkan self-efficacy akademik siswa. Jurnal Bimbingan Konseling 4(I).

Setyawan, Dedy. 20I4. Pembelajaran Matematika yang Mengacu Multiple Inteligences pada Materi Statistik di Kelas XI IPS SMA Negeri 2 Batu. Anterior Jurnal, I4(2):5 I-58.

Sudijono Anas. 20II. Pengantar Statistik Pendidikan, Jakarta: Raja Grafindo Persada.

Sukardi M. 20II. Evaluasi Pendidikan prinsip dan operasionalnya, Jakarta: PT. Bumi Aksara.

Susilana dkk. 2009. Cepti Media Pembelajaran Hakikat Pengembanga, Pemanfaatan dan Penilaian, Bandung: CV. Wacana Prim. 